\title{
Barriers to Third Sector Development
}

\author{
Annette Zimmer and Benedikt Pahl
}

\section{Introduction: A Success Story and a Clouded Horizon}

There are many reasons why the third sector throughout Europe looks back upon a remarkable success story in terms of economic growth, cooperation with governments and civic engagement. Firstly, the unique position of third sector organizations (TSOs) in between "the market" and "the state" allows TSOs to combine the best of these two worlds: the entrepreneurial spirit and energy of the market with the common weal and public good orientation that is generally associated with the state. When governments started to modernize the public sector and looked for partners in the

A. Zimmer $(\bowtie) \bullet$ B. Pahl

Institut für Politikwissenschaft, Westfälische Wilhelms-Universität, Münster, Germany

e-mail: zimmean@uni-muenster.de 
provision of public and social services, statist countries, in particular, opted in favor of welfare partnerships with TSOs (Freise and Zimmer 2004; Osborne and Gaebler 1992). Secondly, very often, TSOs are offspring of the social movements of the 1970s and 1980s, such as the ecological and the women's self-help movements. When these movements were successively institutionalized, they gave way to the establishment of numerous TSOs in many Western European countries (Staggenborg 2013; Johnston and Noakes 2005; Roth and Rucht 2008). Thirdly, in many countries of the Western world, the shift from an industrial to a service economy was accompanied by increased societal affluence. Blue- and white-collar workers had increasingly more leisure time at their disposal that was at least partly invested in activities affiliated with TSOs. As a result, the popularity of expressive TSOs, such as sport or hobby clubs, increased significantly and translated into a remarkable growth of the sector in terms of the number of organizations. In this vein, foundations became more and more popular in many countries, since private wealth had been growing due to Europe's peaceful development after World War II.

Moreover, TSOs in Europe were part of the "third wave of democratization" (Huntington 1991). In Spain and Portugal, repressive authoritarian regimes, which had lasted more than 40 years, finally came to an end in the mid-1970s, giving way to a reintegration of the Mediterranean countries into a democratic Europe. Both countries joined the European Union in 1986 (Dedman 2010). Furthermore, the end of the Soviet Union and the ensuing breakdown of socialist rule in Eastern Europe constituted a further milestone and a remarkable window of opportunity for civic engagement and third sector development. The new and unexpected freedom to organize and to form social groups was heavily used and put to work by social activists and former dissidents all over Eastern Europe. As documented by the work of John Keane (1998) and others (e.g. Mansfeldova et al. 2004; Havel and Keane 1985), the impact of the historic change was reflected in the remarkable growth rate of associations throughout the region. In other words, the third sector can look back upon a remarkable development all over Europe that brought the region full-force into what one scholar termed "a global associational revolution" (Salamon 1994), a significant upsurge of organized voluntary activity not only in Europe, but throughout the world. 
Compared to the 1990 s and 2000s, the general picture facing the third sector in Europe is currently less encouraging. Two decades ago, the future looked bright for the European Union. Central and Eastern European countries, cut off from the dynamic social and economic developments in the West since World War II, were integrated into the European Union, enlarging it to 28 member states. Covering a territory of more 1,600,000 square miles and with a population of over 510 million, the European Union developed into a major political entity. Today, Europe no longer serves as a role model for a harmonic reconciliation of democracy and economic growth. In many European countries, political stability and the reputation of the Union have been put into question. Unemployment rates are stuck at unacceptable levels in many European countries, particularly in the Mediterranean and in Eastern Europe. The Euro hardly managed to survive the economic crisis of 2008. Among the affluent countries in central and northern Europe, tendencies to leave the so-called Euro-Zone are increasingly gaining popularity. Indeed, as opinion polls show, the European Union as a concept has suffered a significant loss of support. Also, civil society, the third sector and its organizations are no longer perceived as key problem solvers by the European Commission. Jacques Delors had a mission and vision regarding the role and function of TSOs in Europe (Delors 2004; Kendall et al. 2009: 347). The Commission under Romano Prodi focused on the "voice function" of TSOs, which was particularly highlighted in the Commission's White Paper on European Governance of 2001 (European Commission 2001). Today, the sector does not enjoy a top priority on the Commission's agenda. If at all, TSOs play a certain role as social enterprises providing public social services (European Commission 2014; Defourny 2014).

Despite these caveats, Europe's third sector is remarkable in terms of size and scope, as clearly shown in Chap. 3. However, several developments have accrued to dim the prospects of Europe's third sector. Before going into detail by focusing on the barriers and hurdles TSOs in Europe are currently confronted with, we will first draw the attention to the enormous variety of the third sector in Europe. In a second step, we will allude to general societal and political trends that might impact on the sector. Among those also is the European Commission as a key actor 
providing funds for TSO activities and, at the same time, supporting fierce competition between for-profit and TSOs in the welfare domain. Against this background, common barriers and problems, almost every country in Europe is confronted with, will be highlighted. The chapter will be concluded by a more facetted picture of how the third sector tries and manages to cope with the identified hurdles in the different European countries.

\section{Third Sector Impact Country Clusters}

There is no question the third sector stands out for its variety in terms of fields of activity, traditions, relationships with government and organizational/legal forms. As Chap. 2 of this report noted, there is no single European law on any of the manifestations of the third sector in Europe. Some countries have no law, others have one or two references embracing the totality of the sector's operations, and others have multiple legal structures pertaining to each of a dozen or more types of third sector entities. As Chap. 3 has shown, the European countries are highly different with respect to the size and scope of the sector.

Under the umbrella of the Third Sector Impact (TSI) project, we undertook a substantial body of research analyzing key barriers for third sector development in the countries under study: Austria, Croatia, France, Germany, the Netherlands, Poland and Spain. The countries were grouped regionally and in accordance to their proximity to a specific pattern of civil society development. Thus, as outlined in Chap. 3 and summarized in Table 5.1, a number of countries in Northern or North Central Europe exhibit a pattern that has been identified as a "welfare

Table 5.1 Grouping of TSI Countries by Pattern of Third Sector Development

\begin{tabular}{ll}
\hline Model & Countries \\
\hline Liberal & UK \\
Welfare partnership & Netherlands, Germany, France, Austria (rural areas) \\
Social democratic & Norway, Austria (urban areas) \\
Statist & Poland, Croatia, Spain* \\
\hline
\end{tabular}

Source: Salamon et al. (2017) 
partnership." Included here among our TSI project countries are the Netherlands, Germany, France and the rural areas of Austria. These countries or regions look back upon a tradition of close cooperation in human service delivery between the third sector and the welfare state. In all, religious politics and strong conservative as well as social-democratic elites kept social welfare provision in the hands of party or religiously affiliated TSOs. In these countries, TSOs have traditionally served a partnership role vis-à-vis the state, particularly in the welfare domain. TSOs in welfare partnership countries used to be protected from commercial competitors, and hence enjoyed privileged access to funding through government protection or, more specifically, through legal regulations. Their TSO sectors have consequently had unusually high levels of government support and a dominance of paid staff in their workforces.

A considerably different pattern emerged in the UK. Here, state support for the third sector, and indeed for social welfare services, has long been far less pronounced than in the welfare partnership countries, a residue of the power of commercial and industrial elites and the historic weakness of labor elements. The mobilization of labor in World War II opened the country to elements of the welfare partnership model, but only partly, leaving behind a third sector more reliant on private than on public resources.

Two of our project countries exhibit a social-democratic model of civil society development, though in one of them (Austria) this reflects a bifurcation of the country's social welfare system between urban-in particular Vienna-and rural areas, with the urban areas displaying a social-democratic model characterized by direct delivery of social welfare services and a third sector much more strongly focused on sports, recreation and expressive activities, while the rural areas exhibit a welfare partnership pattern with the heavy involvement of Church-sponsored organizations.

Finally, three of our countries-Poland, Croatia and Spain-retain distinctive elements of a statist pattern fastened on the countries by modernizing elites in the military or authoritarian parties that restrained third sector development. One of these countries, Spain, is clearly in transition from a statist past to a welfare partnership future, and the other two are on a similar path, but a decade behind. 
As Chap. 3 also notes, and as Salamon and colleagues have pointed out (Salamon et al. 1999; Salamon and Anheier 1998; Salamon et al. 2017), these patterns have not emerged by magic. Rather, they are embedded in historically shaped power relationships among various social forces and governmental institutions that retain influence over extended periods due to the phenomenon of "path dependence." Inevitably, therefore, while TSOs all over Europe are unanimously affected by certain changes in their organizational environment, they can be expected to react differently given the path-dependent course they happen to be on. Hence, although there are broad common trends in how TSOs in Europe are hindered to live up to their potentials, there are also nuances and even exceptions from country to country, and country cluster to country cluster, in how TSOs are affected by the circumstances they face, and we will need to be sensitive to these variations even while documenting whatever general patterns are evident.

To achieve this balance between regional specificity and Europe-wide commonality, each country team of the TSI project conducted an indepth analysis of the country-specific situation of the sector and its organizations. Each team used a mixed-methods approach involving a review of the literature, expert interviews with key stakeholders and an online survey with questions addressed to policy experts and leading third sector practitioners. The findings for each country were summarized in "county reports," ${ }^{1}$ brought to the research team as a whole to identify commonalities as well as regional differences that emerged from the regional inquiries. However, before depicting those barriers and hurdles that are a common problem in almost each of the project countries, we will first provide an assessment of general economic and societal trends that have occurred during the last decades and that have a significant impact on the environment of the sector and its organizations. One of these environmental factors which has to be taken into account is closely related to the European Union and its financial support for the sector in certain regions, as well as to the Union's overall support of a zeitgeist of marketization and competitiveness.

\footnotetext{
${ }^{1}$ See National Reports of the TSI countries: http://thirdsectorimpact.eu/the-project/workingareas/barriers/.
} 


\section{Third Sector Environment}

\subsection{Societal and Economic Trends}

Although the sector looks back on a story of remarkable growth, there are some indicators that might hinder further success. One of these is related to the 2008 financial crisis, which still lingers. Although it originated in the business sector, this crisis fixed on the continent a belief in the recuperative potentials of the market as the engine to get Europe out of its economic doldrums. Governmental austerity became the medicine of choice, starving the public sector and cutting heavily into the financial support to TSOs both nationally and at the EU level.

A second development is related to the impact of the worldwide trend commonly referred to as individualization on TSOs. More, perhaps, than in other regions of the world, European societies used to be drawn to concepts of solidarity and belonging that had not only familial, but also religious and political components. For a long time, citizens in Europe considered themselves born not only into a family and a religion, but also into a broad social group with a shared worldview and sense of mutual obligation. In many European countries such as Austria, Germany or Italy, there were either people of the "right" or people of the "left." And these colorations carried over into the structure of the third sector, which functioned as a transmission belt and central carrier of these respective group concepts. Against this background of normatively divided societies, the notion of "membership" emerged as a synonym for belongingness and lifelong commitment to a specific social camp. Now, however, times have changed and citizens are increasingly less inclined to sign up for lifelong membership and commitment to a specific TSO. This trend is particularly pronounced among the younger generations in Europe. They are no longer interested in membership per se; instead, they prefer to volunteer on a temporary basis and to get engaged in short term activities, or "episodic volunteering" (Beck 1997; Brudney 2010: 1525).

Finally, neoliberalism (Steger and Roy 2010) and its more tangible manifestation in the form of market-oriented reform policies, put in place by the public sector (Wijkström 2011; Zimmer 2014; Maier et al. 
2016; Salamon 1993), had an impact on the sector. Indeed, the first boost of neoliberal thinking and specifically the privatization of social service production opened windows of opportunity for TSOs. In many European countries, particularly in the UK and in the still-developing welfare states of the Mediterranean and post-socialist countries in the South and East of Europe, TSOs became core partners of governments in social service production (Gidron et al. 1992; Salamon 1995). However, nowadays, in the midst of the second wave of privatization, governments are no longer opting in favor of TSOs; on the contrary, the private commercial provision of public services is increasingly challenging service provision through TSOs (Henriksen et al. 2012; Salamon 1993).

This is not to say that the third sector is of rapidly decreasing importance in Europe. However, the distinctiveness of TSOs might be at risk. Also, the societal function of the sector might increasingly be jeopardized. Because of their organizational culture, governance and revenue sources, TSOs belong neither to the efficiency-driven market nor to the authority-driven state. To be part of this sector is to be different from the market and the state in terms of governance, resources, organizational culture as well as mission and vision. It also means to be based significantly on sentiments of solidarity. If TSOs are losing these very special qualities due to external pressures, Europe would be very different from today, without the broad and encompassing variety of TSOs and their contribution to democratic governance, improved service provision and the quality of everyday life of the European people. Whether and to what extent officials in Brussels are aware that an important cornerstone of Europe's identity might be jeopardized if TSOs are hindered from getting the most out of their potentials is difficult to assess. The findings of our research indicate that there is rather limited awareness of the sector's capacity and its potentials.

\subsection{European Union as a Key Actor?}

The question whether the European Union constitutes a key actor for the further advancement of the third sector in Europe has to be answered with a straightforward "yes" and "no." In a nutshell, Whenever TSOs are 
asked about the relevance of Brussels for their daily work, the importance of the European Union is judged as being nonrelevant. But the EU has an impact on the sector and its TSOs in various ways, and the relevance of the EU has been growing over the last decades.

Most obviously, the EU has an impact on the sector in monetary terms through grants and contracts. The relevance for the build-up of the sector in the new member states before accession is without any question. In the accession states, the PHARE program of the EU with its focus on supporting social cohesion paved the way for grassroots initiatives such as small and local TSOs. Currently, in particular TSOs, active in postsocialist countries and in the South of Europe, are profiting from the EU's cohesion policy, specifically from monetary transfers paid out of the European Regional Development Fund (ERDF) and the European Social Fund (ESF) or Structural Fund (Venables 2014). As clearly shown in Chap. 2, public funding continues to be a very important source of revenue for TSOs all over Europe. In structurally deprived areas, such as East Europe, or in regions hit hard by the recession, such as the Mediterranean countries in the South, European money plays a significant role for TSOs, particularly for those that are active in the area of social services, health and education. But, as recent studies also reveal, the EU money goes primarily to larger organizations that are in a position to fulfill the burdensome requirements of EU-grants with respect to application, monitoring and evaluating. This means that EU-funding is heavily biased and supports primarily those TSOs in Europe that are already fairly established. In other words, the EU works in favor of the more business prone TSOs while simultaneously being disadvantageous for small and community oriented ones. ${ }^{2}$

A further impact on the sector is closely related to the EU's overall political agenda of fostering competition between different providers of goods and services within the European Union. In this respect, the EU is indeed a driving force. Since the early beginnings of the Common Market, the EU has pushed into the direction of competiveness and has worked in favor of a primarily market-driven integration process (Boje

\footnotetext{
${ }^{2}$ See National Reports of the TSI countries: http://thirdsectorimpact.eu/the-project/workingareas/barriers/.
} 
and Potucek 2011). A textbook example constitutes the Directive on Services of General Economic Interest that was highly disputed about two decades ago (Zimmer et al. 2009: 33; Kendall et al. 2009: 358). In its original contours, the Directive directly jeopardized the model of third sector embeddedness in the welfare partnership countries. TSOs active in core welfare domains in social and health services were supposed to be treated on equal footing with commercial providers. Furthermore, public grants as well as sponsorships of companies supporting TSOs-most likely in sports-were considered to be subsidies that cause market disruption and therefore should be significantly restricted or totally banned by European law. Hence, the directive designed by the DG for Internal Market originally treated any human service like a commodity that was to become subject to similar regulations than any other marketable good. In the end, the directive was watered down in such a way that the specificity of TSOs active in human services was finally acknowledged. TSOs successfully argued that they are distinct from for-profit providers because they are working close to their communities, which is evidenced by the many volunteers who are engaged locally in the provision of social services delivered by TSOs.

But despite the EU's concession, the majority of European governments enacted the directive in very much the way it was originally intended by the European Union (2012). Hence, the EU's impact on TSOs in Europe is rather implicit but, nevertheless, the EU strongly influences the environment of the sector, specifically, in terms of fostering an overall culture of competiveness that downsizes the relevance of other mechanisms of co-ordination such as solidarity or community orientation. In parallel to the enactment of the Directive, instruments of NPM were introduced in the EU member states that had a deep and lasting influence on third sector government relationships. Key features of NPM instruments such as competitive tendering and contract management go along with encompassing and time-consuming procurement procedures, which are difficult to handle, specifically for small TSOs, since the organizations have to devote a considerable amount of time for administration, reporting and book-keeping. All in all, the decisive change of third sector government relationships, at least partly inaugurated by the EU, resulted in the increased bureaucratization of the TSO governance. 
Finally and controversially discussed is the impact of the so-called European third sector community that consists of encompassing third sector umbrella organizations operating in Brussels (Kendall et al. 2009). The so-called European TSOs are working as lobbyists on behalf of the sector in Brussels in close contact with the EU policy machinery, the Commission, the Parliament and the various interdepartmental groups (Kendall et al. 2009). Partly funded and sometimes even founded by EU institutions, the so-called community of European TSOs operating in Brussels is somehow in a position of dependency. It has a low profile and seems to serve a useful function for the EU's policy machine by providing expertise and also legitimacy for selected policies, initiated by the Commission. TSOs active in Brussels are not at all in a position of being able to significantly influence the agenda or addressing major topics that are key concerns of the EU and directly and indirectly impinge TSOs' fortunes in the European member states such as the liberalization of social service provision, the introduction of rigid and highly bureaucratic procurement procedures, the neglect of the added value of TSO activity in terms of community building and civicness, just to name a few (Zimmer and Hoemke 2016).

In sum: Although the EU does not have a direct impact on TSOs in Europe, the EU exercises a remarkable influence on the environment of European TSOs by both neglecting the third sector as a valuable underpinning of the social fabric of Europe and exclusively supporting third sector activities that are business-like and favorable for the economy. Moreover, the "cultural shift" toward marketization in third sector government relationships as well as the increase in bureaucratic control mechanisms, on which we will focus in the following chapter, has been promoted and significantly supported by the European Union. Therefore, the impact of the European Union translates into a homogenization of the barriers TSOs have to cope with; however, these barriers play out very differently in the countries due to the heterogeneity and diversity of TSO embeddedness in the European regions.

In the following, we will draw heavily on the results of country reports of the TSI team. ${ }^{3}$ Thanks to the reports, we were able to identify both

\footnotetext{
${ }^{3}$ See National Reports of the TSI countries: http://thirdsectorimpact.eu/the-project/workingareas/barriers/.
} 
common problems with which TSOs in all the European countries are confronted and difficulties that are region- or country-specific. We will firstly depict the common problems and secondly turn to barriers and hurdles that are an outcome of the legacy of history and belongingness of the sector to a particular pattern and/or country cluster.

\section{$4 \quad$ Barriers to Third Sector Development}

\subsection{Common Barriers}

Despite the variety of developmental trajectories of the sector in Europe, we identified common barriers standing in the way of TSOs in almost every project country. Graphs and tables presented in the following are based on the results of online surveys conducted in the project countries. Representatives of TSO umbrellas, high profile managers and experts in the field were invited to fill out an online questionnaire. Our intention was to conduct a "stakeholder survey," the goal of which was to find out what stakeholders working at the organizational level of the sector think about general trends within the sector, indicating which barriers and difficulties they perceive as the most salient regarding the current situation and the development of the sector in the future (see Appendix on the data gathering process).

The results of the surveys show that the sector in Europe is confronted with a serious set of problems that translate into:

- financial barriers,

- human resource/governance barriers, and

- external relation barriers/overload of bureaucratic requirements (Zimmer and Pahl 2016).

As the graphs indicate, the identified barriers play out differently in the project countries, thus reflecting and underlining the embeddedness of TSOs in different environments. Although TSOs are confronted with financial barriers all over Europe, the lack of public funding is perceived as a very serious barrier, particularly in the post-communist countries (Fig. 5.1). 


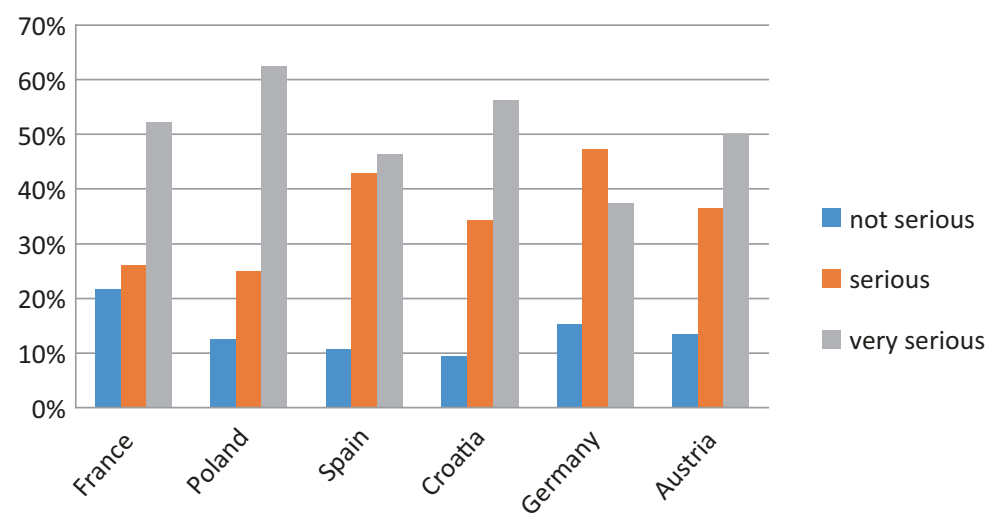

Fig. 5.1 Financial Barrier: Lack of Public Funding. Source: Zimmer and Pahl (2016: 10)

Asked to assess the financial situation of the sector and to indicate the financial difficulties with which TSOs in the country are currently struggling the most, it turned out that "public sector underfunding" constitutes a major barrier and hence a serious or even very serious problem. However, as outlined in the country reports, the reasons why stakeholders are concerned about the lack of public resources are different. In the case of Croatia and Poland, there are hardly any alternative sources of financing available and the countries are significantly hit by the crisis. This is also true for France and Spain. The situation is different in Austria and Germany. Here, the modes of public financing have changed significantly in the last decades. TSOs are working primarily on grant money, which constitutes a "commodity" and not a monetary support for the sector. TSOs, particularly those working in the social domain, are paid on a per capita basis. For each service delivery, TSOs receive a fixed amount of money that is agreed upon in a process of competitive tendering among various service providers-for-profit and nonprofit organizations. Hence, TSOs in these countries are struggling with difficulties in financing their infrastructure because they almost exclusively work with contract money (Fig. 5.2).

Asked to assess which are the most serious difficulties related to human resource management, recruitment of volunteers turned out to be rated 


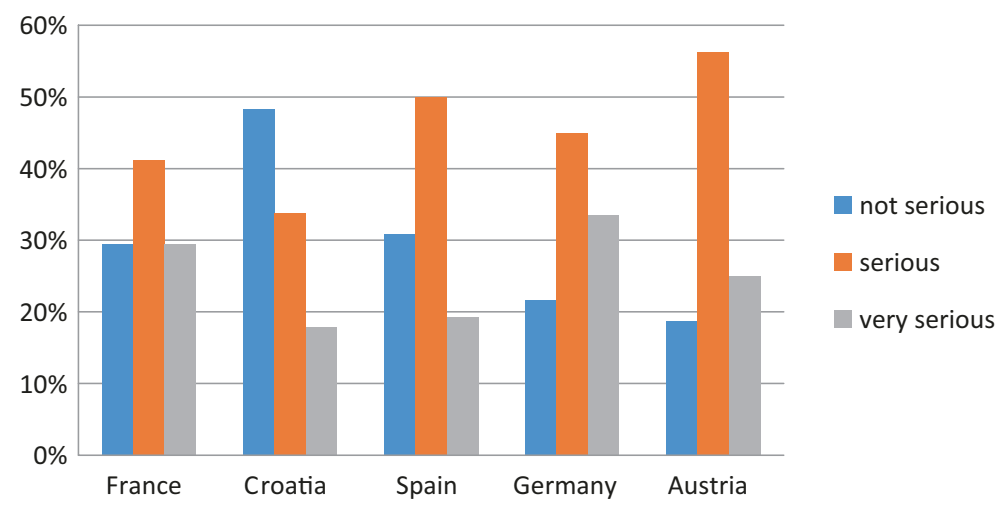

Fig. 5.2 Human Resource Barrier: Difficulties Recruiting Volunteers. Source: Zimmer and Pahl (2016: 6)

as a serious or even very serious problem in particular by stakeholders from Austria and Germany, countries which belong to the welfare partnership cluster. The reasons for this rating might be linked to trends of individualization and societal pluralization that have a deep impact on German and Austrian society, with the effect that volunteer engagement in a specific TSO, either positioned in the conservative or the more liberal camp, does no longer correspond to the Zeitgeist in these countries. In particular, Austria and Germany look back upon a legacy of divided societies, structured into social camps of "the left" and "the right" that carried over into the structure of the sector. In France and Croatia, volunteering has never been very popular. This might be the reason why stakeholders perceive the recruitment problem as less serious than their counterparts in the welfare partnership countries. The reason why, on the contrary, Spanish stakeholders are concerned about volunteer recruitment might mirror the current situation of a sector that is in a state of transition, in which the impact of former state dominance is more and more on the retreat (Fig. 5.3).

Responses to the question concerning the governance of TSOs, specifically, whether there are difficulties in recruiting board members and hence attracting citizens to take on positions of authority on a voluntary basis, turns out to provide a very clear picture. With the only exception of Croatia, recruitment of board members is perceived as a significant or 
even crucial problem in the majority of the project countries. There are many reasons why this is the case. Serving on a board and being a trustee of a TSO is hard work, time-consuming and demanding in terms of required qualities and responsibilities, which come with the position. As an effect of the generalization of quasi-markets, particularly in the social service domain, managing TSOs has become more demanding. Simultaneously, control mechanisms have been intensified, which translates into a transformation of TSOs in far more bureaucratic organizations with the outcome that expertise in business administration is needed in order to be capable of managing and supervising TSOs today (Fig. 5.4).

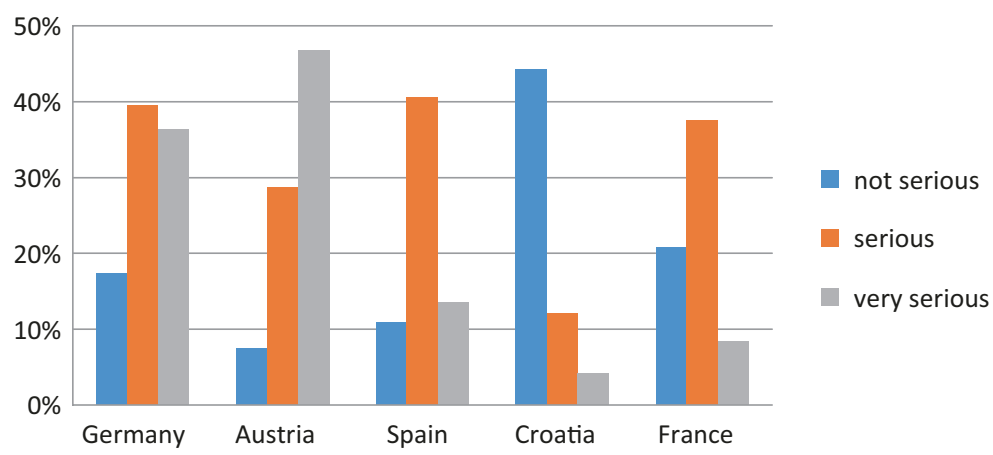

Fig. 5.3 Human Resource Barrier: Difficulties Recruiting Board Members. Source: Zimmer and Pahl (2016: 7)

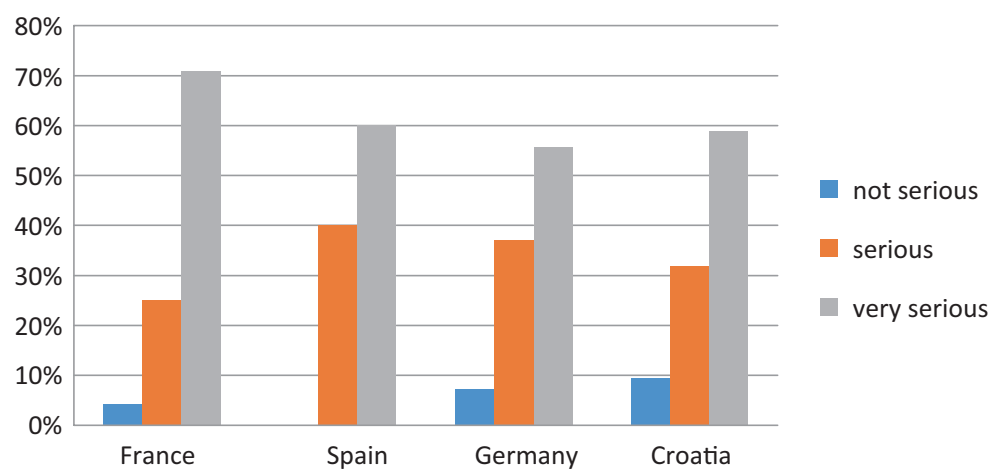

Fig. 5.4 External Relations Barrier: Increasing Bureaucracy. Source: Zimmer and Pahl (2016: 8) 
Asked which aspect, from their point of view, constitutes the most pressing problem as regards the external relations of TSOs, "increasing bureaucracy" was named first. Again, the assessment of the stakeholders reflects the significant changes of the sector's environment in Europe. Today, TSOs in the majority of European countries are treated on par with for-profit providers, in particular, in the area of social service provision where they almost exclusively work on contracts. The new policy environment impacts significantly on third sector government relations. These used to be trust based at eye level and changed to a customer-supplier relationship. Nowadays, TSOs have to prove that they are thoroughly in compliance with their contracts. Today, this results in a situation where a significant amount of time, which in former times was available for the "real work," has to be allocated to record keeping and documentation of costs. This is specifically the case in Germany, France and partly also in Spain. In contrast, TSOs in Croatia are still perceived as somehow untrustworthy partners of governments, which simultaneously reflects the statist tradition of the country. The reason why TSOs in Croatia are faced with increased demands for documentation and control are slightly different form the situation in the "welfare partnership countries", as we will outline in the following chapter (Fig. 5.5).

Marketization might come at a price for TSOs. Social service provision is under rigid cost-containment strategies enforced by government. TSOs working in this area are acting in very competitive markets, in which they

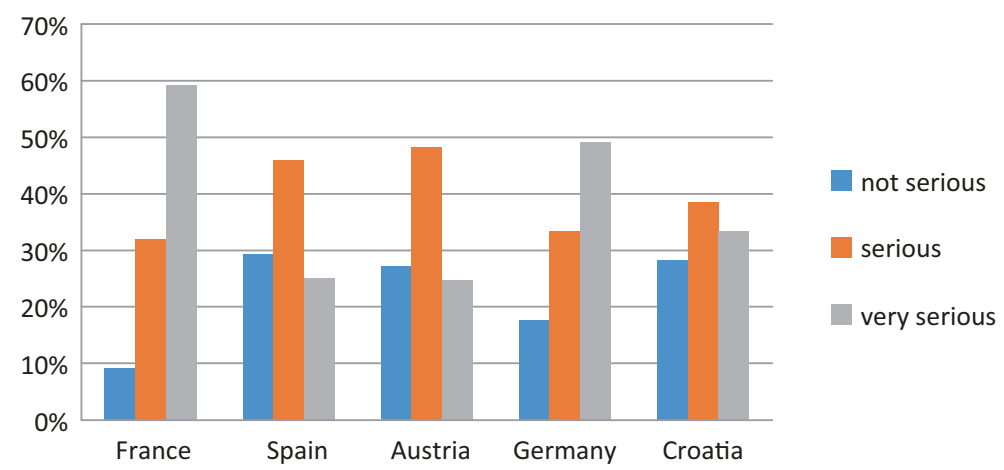

Fig. 5.5 External Relations Barrier: Low Pay of Employees. Source: Zimmer and Pahl (2016: 11) 
are challenged by efficiency-driven for-profits. In order not to lose ground, TSOs have to bring production costs down. Reducing the costs of labor might offer a way to be competitive. Against this background, our stakeholders indicated that TSOs in some areas are not able to pay decent wages. Participants in our survey rated "low pay of employees" as a key issue with which TSOs in their countries are struggling. This might not come as a surprise in countries where TSO-government relationships are still in a developmental stage. However, it is worrisome that stakeholders of the welfare partnership countries Germany, Austria and France perceive low pay of employees as a major barrier, which might decrease the attractiveness of TSOs on the labor market in the long run, even if this is not yet the case. As stressed by the TSI teams and clearly underlined by the UK report, "it is noteworthy that very few respondents pointed to problems with their paid workforce, in terms of recruitment, quality, training or motivation" (Kendall et al. 2016a, b). However, the attractiveness of the sector, which up until now has been a central reason for its remarkable growth, might not be durable. Asked to assess how they see the future of the sector, the majority of stakeholders is reluctant and prefers a conservative and careful view into the future, indicating that they strongly or rather disagree (70 percent) with an overall optimistic preview that "the next ten years might be easier for TSOs than the previous ten" (Hoemke et al. 2016: 15). Although skepticism turned out to be a general trend all over Europe, the TSI research team also unfolded variant trajectories of third sector development as well as significant differences between the European countries as they are affected by the afore-described changes of the environment.

\subsection{Regional Diversity and Regime-specific Barriers to TSO Development}

\subsubsection{From Liberal to Welfare Partnership to Liberal Again- The UK}

In the UK, TSOs see their environment as increasingly market-driven in terms of resources and governance practices, the result of a shift in the 
political climate and ideological discourses from an incipient welfare partnership model back to an earlier liberal, now neoliberal, marketoriented model (Kendall et al. 2016a, b; Mohan et al. 2016; Kendall and Knapp 1996).

After moving from a historically liberal pattern of third sector development, until the expansion of the British welfare state in the aftermath of World War II and the adoption of key features of a social-democratic model, the UK third sector became a beneficiary of the Third Way political philosophy of the post-Thatcher Labour government, which adopted key features of the welfare partnership model involving the increased reliance of government on TSOs to deliver social welfare services. The state was assigned a more passive role as an enabler and not as a provider of welfare activities. The third sector policies were meant to be achieved via enabling the emergence of a quasi-market with preferences for standardization and large-scale provision. Thus, large organizations were able to deal with the challenges regarding procurement, commissioning and contracting to the detriment of more specialized responses to needs.

Furthermore, the Labour government made major investments into a third sector infrastructure and into the organizational capacity of TSOs. As one reflection of this, following the advice of a special commission on the third sector created by a group of foundations (the Deakin Commission) a concordat or compact between the government and third sector was initiated. However, against the background of the required marketization and professionalization that was also pursued, many organizations were not able to, or did not wish to, work with government as a partner in such a marketized climate of operations.

With the entry of the Cameron coalition government, the philosophy of "Big Society" provided the ideological backbone for a return to the traditional UK Liberal Model featuring an independently financed third sector and hostility toward state involvement in terms of public spending. In a nutshell, the government program envisaged scaling back public expenses, which were to be replaced by volunteers, or in other words, the "Big Society" substituting for "Big Government." In practice, quasimarkets were extended and welfare services were opened to market forces as far as possible. For-profit agencies were granted (market) access to all policy fields, including voluntarism and work with vulnerable groups. 
Besides quasi-market approaches, the UK governments, mostly with the new legislation in 2016, have fostered financing models that follow a social investment logic, such as loan and bond finance initiatives. Hence, these sorts of schemes have gained relevance among British TSOs.

Extensive budgetary cuts went hand-in-hand with market promotion in all areas of welfare spending, with the financial crisis providing the legitimacy to far-reaching austerity policies. In particular, the budgets of local authorities, which are a core source for third sector funding in the UK, were massively reduced. Additionally, the third sector infrastructure, which the Labour government had set up or substantially supported — like the Charity Commission and the Office for Civil Society-was cut back. As the sectoral infrastructure has collapsed and the financial support from local authorities has been cut, TSOs face difficulties to function properly. Especially the capacity to mobilize and encourage volunteer contribution is severely diminished. The case of the UK provides an example that volunteering does not work properly if an appropriate infrastructure is lacking. Furthermore, the Cameron government took a hostile stance toward the campaigning and advocacy work of TSOs, stating that the use of public grants for campaigning activities would be prohibited. Generally, the British Third Sector's ability to perform its multiple roles seems to be increasingly constrained because its organizations are facing the double challenge of reduced public funding (austerity) and intensifying scrutiny through statutory bodies and an increasingly critical national media (Kendall et al. 2016a, b). Summarizing the general picture, the UK report underlines that "significant numbers of organizations experience their environment as increasingly market and quasi-market driven in terms of resource origins and governance practices, and experience the current political climate as unconducive to non-service provision roles" (Kendall et al. 2016).

\subsubsection{Welfare Partnership Countries: Adjustment to a Changed Social Policy Environment-Germany, the Netherlands, Austria}

Unrivaled welfare partnership in the social domain used to be the central feature of the third sector in these countries (Brandsen and Pape 2016; 
Simsa et al. 2015, b; Hoemke et al. 2016). Deeply embedded in the institutional design of the welfare state, TSOs enjoyed a privileged position as providers of social services. However, in response to the neoliberal surge, the policy environment in this cluster of countries has changed significantly in the last decades. The welfare partnership, based on secured public funding for TSOs, which were legally protected from competition of alternative providers, was modified in such a way that today TSOs are treated on par with commercial providers. Secured public funding for TSOs is a story of the past. Alongside the introduction of NPM, competitive tendering and contract management have become ubiquitous in the social domain. Furthermore, commercial providers successfully made inroads into areas of social service provision that used to be core domains of TSOs—such as hospitals or child-care facilities. Indeed, TSOs are nowadays confronted with increased competition from for-profit providers in every field of social service provision. The changed policy environment has a deep impact on the governance and organizational culture of TSOs. In order to survive in these by now highly competitive markets for social and health services, TSOs have to be efficiently managed. Hence, the "marketization" of the social domain translates into a situation in which TSOs turn to "managerialism" as a business-like way of governance and management.

From an economic point of view, many TSOs accomplished the shift toward a professionally managed nonprofit enterprise successfully. Despite the mounting cost and efficiency pressures, TSOs in this cluster of countries have defended their positions as core providers of social services. The market share of TSOs in the social domain is relatively stable compared to the share of for-profit competitors. As TSOs look back upon a long tradition and expertise in service provision in many fields of human service delivery, such as health care or child care, they are able to compete successfully with commercial providers in competitive tendering procedures. Also, TSOs are able to communicate their professionalism to the general public. Compared to the UK, where the media increasingly looks upon TSOs with skepticism, in particular, the religiously affiliated "big players" among the third sector service providers, such as the Caritas in Austria and Germany, enjoy a good reputation among the general public. Against this background, TSOs can rely on an established brand as a 
social service provider that constitutes an asset compared to new commercial competitors that have to create awareness among customers. Moreover, TSOs can count on good relations with local politicians and administrators, which enable TSOs to improve their position in negotiations for service contracts. However, the successful adaptation of TSOs in competitive markets comes at a price: there are indicators that TSOs might lose some of the specific qualities that are commonly attributed to the sector. The "winds of change," which might endanger the core values of TSOs in Austria, Germany and the Netherlands, are the change of the legal form toward a limited liability company, the preference for professional managers with a background in business administration instead of, for example, social work, and the decreasing attractiveness of TSOs for volunteers.

TSOs are still providing important avenues for civic engagement and volunteering in the countries of this cluster. However, they seem to lose their pole position as the key terrain for volunteer engagement. As outlined earlier, Europeans have long considered themselves born not only into a family and a religion, but also into a broad social group with a shared worldview and a sense of mutual obligation. Being an active member in terms of both volunteering on a regular basis and serving on a board of a TSO used to be key ingredients of the way of life for the majority of citizens in these countries. The reason for the steady volunteer influx into the sector was that the societies of this country cluster used to be highly structured and organized into religious or ideological communities, of which TSOs served as the organizational underpinning and infrastructure. For describing this phenomenon, "pillarization" is used in the Netherlands, while in Germany and Austria, the "social milieu" is referred to frequently (Brandsen 2011; Golbeck 2011: 92; Zimmer 2013). However, both the societal pillars of the Netherlands and the social milieus of Austria and Germany-of which the catholic and the social democratic used to be the most important ones-are no longer strongly in place. Citizens born into these pillars and/or social milieus used to constitute a stable resource base of volunteers for TSOs of a respective pillar or milieu. Since the pillars and milieus are almost gone, the religious and ideological bonds to TSOs have significantly eroded. Citizens are no longer born into a pillar or milieu that used to pave the 
way for lifelong engagement for a particular TSO. Accordingly, nowadays, TSOs have to actively recruit volunteers. With respect to voluntary contributions, such as donations, volunteering and serving on boards, TSOs are faced with a competitive environment, similar to the one they encounter on the market for government grants and contracts. Additionally, a growing share of volunteering takes place independently and without the framing of TSOs.

As regards the key topic of our inquiry, the Austrian report summarized, "One of the biggest barriers of TSOs stems from the lack of financial resources (Simsa et al. 2015, b).” The combined lack of public funding and private donations as well as the decreasing profit margins from TSOs' market activities result in an ongoing trend toward marketization and professionalization, which will most likely impact negatively on the social and civic mission of the sector. TSOs in the welfare partnership countries are confronted with problems of identity and legitimacy since they are becoming more and more business-like in order to hold their central position in the market domain of social service provision.

\subsubsection{The Social-Democratic Model on the Retreat}

Scandinavian countries like Norway exhibit a "social-democratic" pattern of third sector development in which the sector is heavily focused on expressive functions such as sports, recreation and culture, with high levels of volunteer involvement and relatively little government support (Lundström and Wijkström 1997; Wijkström and Zimmer 2011). Social service provision is not perceived as a function of TSOs; instead, the social domain is generally acknowledged to be a core area of welfare state activity. For decades, social services used to be government-regulated, generously financed through tax money and, with very few exceptions, delivered by government entities.

However, in line with the trends in other European regions, the Scandinavian countries have begun to implement NPM tools to regulate relations between public contracting authorities and providers of welfare services. Local governments made an internal separation between contracting authorities and providers of services in the beginning of the nine- 
ties in Sweden (Erlandsson et al. 2013: 27) and late in the nineties in Denmark and Norway (Vabø et al. 2013: 171). Since then, contract negotiations or competitive tendering have replaced agreements between public purchasers and service providers, which otherwise would have been renewed almost automatically. The reason why this is the case is closely linked to the overall assessment of public policy and, particularly, social policy. In a nutshell, public institutions are no longer perceived to be capable of responding to social needs adequately; instead, in line with neoliberal thinking, the market and hence competition between different providers-for-profit and nonprofit - is supposed to provide social services efficiently, appropriately and in accordance with the needs and preferences of the clients. The roll back of the state in social service provision is still very much in its infancy in Scandinavia. However, at least in Sweden and Denmark, the share of for-profit providers in the welfare domain is slightly increasing, while employment in the public sector has started to decrease. In Norway, with no need for austerity measures because of the income from oil production, all three sectors still grow in real numbers, although the public sector's share is decreasing (Sivesind 2017).

What might work against the sector and in the long run might impact negatively on TSOs is related to the overall image of the sector in the Scandinavian countries. It is reported that in Norway public authorities are not particularly interested in the distinctive profiles of TSOs (Trætteberg and Sivesind 2015). Furthermore, if we look at the expressive TSOs in Norway, there is a decline in formal membership, indicating an erosion of bonds between TSOs and their members. At the same time, surveys report an increase in volunteering. In Norway, 61 percent of the adult population volunteer at least once a year. However, volunteers are not necessarily members of TSOs, and if so, they tend to move from one TSO to another. Very similar to the pluralization of the societies in the "welfare partnership countries," the collective identities on which volunteering in Scandinavia used to be based are no longer strongly in place. These identities were closely connected to the traditional Scandinavian popular movements, such as consumer cooperative movements (Hilson 2010). Today, similar to other European regions in the Scandinavian countries, volunteering is first and foremost connected with conceptions of self-expression and self-realization. This may indicate that the sector's 
role as part of the democratic infrastructure of the country has diminished with the decline of the traditional popular movements. Simultaneously, TSOs have not managed to make inroads into the markets of social service delivery, which have just started to develop due to the most recent social policy changes.

\subsubsection{Struggling with the Past and Catching up on the Edge: Croatia and Poland}

Poland and Croatia exemplify the power of path dependence in shaping a pattern of third sector development highly influenced by past realities (Leś et al. 2016; Bežovan et al. 2016). Like other third sectors exhibiting the classic features of the statist pattern of civil society development, Eastern European third sectors were subject to an authoritarian state that pursued modernization and social control from the top, and was eager to avoid disruptive third sector elements raising objections from below. TSOs in the realm of the church, sports and TSOs in the social economy, such as cooperatives, were partly able to survive. In addition, the state organized its own third sector-type entities, particularly in the professions and labor, but these were most likely controlled by the state and therefore outside the kind of definition of the third sector identified in Chap. 2 of this report. Conjointly, support structures for the third sector were brought under state control. Reflecting this, the third sector in Poland and Croatia remains fragmented and relatively small compared to the third sector particularly in the welfare partnership countries. Also, the societal embeddedness of the sector in terms of volunteering and giving is still very limited compared to Western European standards. The majority of TSOs are expressive organizations working in the areas of leisure and sports. In both countries, cooperation with government in the social service domain is still in its infancy. Funding continues to be a difficult issue for TSOs in the region and has deteriorated due to the financial crises and austerity measures put in place by government. If there were no EU-support, many TSOs in Poland and Croatia would probably be forced to stop operating.

Although the two countries share many commonalities, there are also striking differences that again are linked to history. It is worthwhile to 
stress that Poland was the pioneer among the countries in Eastern Europe to stand up against Soviet rule and to develop under the leadership of a third society organization - the trade union Solidarnosc — a societal and political alternative that facilitated peaceful transition and democratization all over the region. Although the Catholic Church in Poland has always been traditional and quite conservative, the charismatic Pope John Paul II, born as Karol Józef Wojtyła, supported the process of transformation. However, even today, there is a divide between the rural, conservative and very catholic countryside and the more liberal, open-minded and somehow even rebellious urban Poland. In particular, in Warsaw, but also in other major cities, TSOs are very active addressing societal issues and problems that are not taken up by government (Siemieńska et al. 2016). In addition, TSOs are of increasing importance in the field of education (schools) in Poland (Leś et al. 2016: 14). When the government, due to fiscal difficulties, began to close down schools in urban neighborhoods as well as in the country side, TSOs— set up and financed by citizens - stepped in with the goal of providing an educational infrastructure that is easily accessible and nearby (Siemieńska et al. 2011). These examples indicate that TSOs in Poland enjoy the backing of local communities and case-related constituencies.

Compared to Poland, the development of the sector in Croatia did not start from below. Instead, as the authors of the country report outline, third sector activities were activated from "outside" (Bežovan et al. 2016). The atrocities of the civil war resulted in an influx of many TSOs, which were and, partly, still are funded and supported by foreign money. A large part of the sector in Croatia still consists of humanitarian TSOs. This, in turn, has nurtured general skepticism toward the sector as being a product of Western intervention in Croatian society. Lack of trust combined with the low profile of the sector in Croatian society continues to be a significant hurdle, which impacts negatively on the sector's further development. Moreover, in Croatia and partly also in Poland, government was and still is reluctant to partner with TSOs in the provision of social services. It took more than ten years to clarify legal issues and to set up a framework for cooperation between public institutions and TSOs in the two countries (Rymsza 2013; Bežovan et al. 2016). Even today, social service providing TSOs play a very minor role in both countries. A lack 
of public awareness and a lack of trust on the part of both citizens and state authorities in the professionalism and capacity of TSOs are reported to be crucial barriers for the flourishing of TSOs in the social service domain. Furthermore, contracting with public authorities is troublesome and TSOs are partly discriminated against by public providers by practices of clientelism and the opaque nature of contracting procedures. As already mentioned, the low social anchorage of TSOs is reflected in the limited degree of private giving. Additionally, public funds are increasingly limited due to cost-containment strategies as well as policies of austerity in both countries. On the grounds that alternative financial sources are missing to compensate for the tense situation of the public purse, EU funds are of particular significance for TSOs in Poland and Croatia, as well as all over Eastern Europe. In fact, EU funds have been crucial to the growth of the sector in the region (Zimmer and Hoemke 2016). As EU funds are very complex and bureaucratic, highly professionalized organizations have evolved around EU-funded themes. However, rigid control and an overload of bureaucracy are not restricted to EU funding; public support also increasingly comes with the high prize of intensified control procedures and book-keeping requirements. As the national report of the Croatian TSI team neatly summarized, the key barriers to the development of TSOs in the region are "the path-dependent problem of lacking awareness, the government quasi-monopoly of providing social services, the deficient implementation of policies advancing welfare partnerships between government and TSOs and finally the low levels of citizen engagement in terms of volunteering and private giving" (Bežovan et al. 2016; Leś et al. 2016).

\subsubsection{In between Statism and Welfare Partnership: France and Spain}

Until the 1970s, with the demise of the Franco regime, Spain had most of the features of the statist model of civil society development, with limited third sector institutions and little government support for them (Chanial and Laville 2014; Petrella et al. 2016; Chaves et al. 2016). During the dictatorship, large parts of the sector were suppressed and the 
Spanish third sector is still underdeveloped compared to France or Central Europe. France is a slightly different case, though its historic opposition to third society organizations reflecting Rousseau-ist sentiments born out of the French Revolution and the etatist nature of its social welfare system well into the post-World War II era gave it many of the features of the statist model as well (Archambault 1997). Volunteering is low in both countries. Particularly in Spain, volunteering is more directed toward one's next of kin. Both countries, but particularly Spain, also featured substantial social economy units in the form of cooperatives and mutuals, though these are heavily commercial in orientation and only a small segment of the cooperative sector operates under the binding limitation on the distribution of profits stipulated in the in-scope definition of the TSE sector formulated in this project.

Current scholarly discourse as well as policy development are focusing on the Social and Solidarity Economy (SSE), in particular, in France. Faced with a difficult economic situation, social economy might provide tools for reforming social service delivery in a way that citizens might get the same quantity and quality of services while government spends less. France's welfare state is highly developed and, according to OECD data, ranks among the top spenders (Chabanet 2016). Alongside policies of decentralization, the sector has developed into a prime partner of government with respect to social service delivery. The embracement of the sector by the welfare state resulted in a success story and in the remarkable growth of the third sector in France. In accordance with the welfare partnership mode, France's third sector today constitutes a highly integrated component of the country's welfare state (Archambault et al. 2013). However, similar to Spain, France is severely hit by the crisis. As a reaction, government provides incentives for TSOs to become more businesslike and for for-profits to get active in those areas and fields, which used to be earmarked for TSO engagement, such as social services. As a result, relationships between TSOs and public authorities are deeply affected. According to the French national report, TSOs are increasingly perceived just as "service providers" instead of co-producers of public policies. Since French authorities acknowledge the civic values of the sector far less than previously, the advocacy and social integration functions of the sector might be jeopardized. 
In this respect, the current state of affairs of the sector in France and the barriers the sector currently is confronted with are quite similar to those that are encountered by the sector in the classical welfare partnership countries Germany, Austria and the Netherlands.

Beginning in the mid-1970s in Spain and in the 1980s in France, significant elements of the welfare partnership model have emerged. In Spain, this transformation has been significantly aided by an influx of EU funds as national funding of social welfare activity remains relatively low and concentrated on old age pensions. Locally financed social services are rather underdeveloped and the extended family still compensates for the lack of welfare institutions. A few privileged "quango" organizations benefited from a moderate welfare expansion since the democratization of Spain in 1978 and the majority of public funds toward the sector concentrate on these organizations. In France, a major shift in social welfare policy in the 1980s helped usher in key elements of the welfare partnership pattern as the state decentralized welfare services and local governments turned extensively toward newly strengthened TSOs to deliver the services. In both counties, however, the sector is fragmented and divided along societal cleavages between secular and religious as well as left wing and right wing organizations. Against this background, the support structure is scattered and underdeveloped. With the financial crisis in Spain, new organizations have emerged in the course of the anti-austerity protests in 2008. These new organizations are not linked to the established "quango" organizations.

Particularly Spain was hit hard by the financial crisis. Public funding was cut due to vast austerity measures. Additionally, private donations decreased mostly due to the collapse of savings banks. Likewise, the social needs of the population escalated due to mass unemployment and social deprivation. Thus, TSOs in Spain have to survive in a particularly hostile environment "having to address more needs with fewer resources" (Chaves et al. 2016).

TSOs have reacted to the crisis by lowering the working hours and extending part time work. Despite the fact that it is difficult for TSOs to recruit volunteers in light of a relatively low social embeddedness of the sector and the increasingly resource-intensive management of volunteers, paid employment is substituted by volunteers. Thus, working hours per 
volunteer have been rising. Furthermore, since TSOs have to manage an increasing deficit, debts are increasing (Chaves et al. 2016; Petrella et al. 2016). TSOs are struggling in Spain to make ends meet; however, compared to Poland and particularly Croatia, the sector enjoys a favorable public image, TSOs active in the social domain are linked to powerful umbrellas, specifically, to ONCE, Red Cross and Caritas (Chaves et al. 2016), and recently, a major support infrastructure was set up-the Spanish Social Third Sector Platform. On the other hand, the sector in Spain is also confronted with significant difficulties in developing further into the direction of the welfare partnership model. There is a lack of awareness of the social and economic impact of the sector; politicians and government officials tend to overlook the sector while designing public policies. Finally, clearly indicated in the Spanish national report on the sector are the difficulties firstly to assess and secondly to work with EU funds. Also, in Spain, working with public funds comes along with increased requirements for control, and hence bureaucracy.

In summary, the third sector struggles with a scarcity of resources and increasing difficulties to cope with those administrative demands that are most likely a side effect of the introduction of NPM instruments in Europe. It seems that TSOs have to invest time and organizational capacity to comply with administrative and monitoring requirements of funders and/or contracting partners. Furthermore, due to changes in their environment, TSOs are forced to act more and more business-like. If we perceive working with volunteers as a special ingredient of TSOs, during the last decades, it has become more difficult for TSOs to be volunteer-based in terms of both their labor force and their governance structures. In order to be competitive, TSOs tend to reduce the cost of their labor force. However, the organizations are aware that in the future this might cause problems, since the low-pay jobs offered by TSOs might be less attractive for highly qualified personnel. "To get the right person for the job" also constitutes a big problem for the governance of TSOs that look upon a tradition of being managed and/or supervised by board members serving in honorary positions. Nowadays, there is a decreasing interest in taking over these positions. In the next chapter, we will turn to the topic of how to address the identified barriers appropriately and to develop a policy agenda that indicates "the way ahead" for the third sector in Europe. 


\section{Appendix}

\section{Stakeholder Survey}

An online survey was conducted with the aim of prioritizing the barriers, which were identified through interviews and focus groups realized with stakeholders in the project countries. With a special eye on the identified barriers, the design of the survey (items) paralleled the manual for the interviews. It is noteworthy to underline that the outcome of the survey is not representative. Instead, it constitutes an evaluation and personal assessment of those who participated in the survey. We addressed stakeholders, such as managers, heads of departments, and board members of TSOs, to take part in the survey. The number of respondents was 250 in Germany, 171 in Croatia and 102 in Austria. The response rate was very low in Spain (28 responses), France (24) and Poland (8). For these countries, the results of the survey are merely illustrative.

In the UK and the Netherlands, the questionnaire of the online survey was adapted to better reflect the national situations. Therefore, the results of the surveys conducted in these two countries are not included in the analysis. However, the outcome of the surveys in the UK and the Netherlands point in the same direction, that is, indicating the same barriers. The response rate was 1200 in the UK, 372 in the Netherlands.

The outcome of the online survey reflects the priorization of the respondents as to which barriers and hurdles they perceive as the most important and salient ones for the TSOs they are either representing (board members) or working for. The results of the survey and the interviews were published in individual working papers per project country and made available on the website of the project.

\section{References}

Archambault, E. (1997). The nonprofit sector in France. Manchester: Manchester University Press.

Archambault, E., Priller, E., \& Zimmer, A. (2013). European civil societies compared: Typically German-Typically French? Voluntas: International Journal of Voluntary and Non-profit Organisations, 24(1), 1-24. 
Beck, U. (Ed.). (1997). Kinder der Freiheit. (Edition Zweite Moderne). Frankfurt: Suhrkamp Verlag.

Bežovan, G., Matančević, J., \& Baturina, D. (2016). Identifying external and internal barriers to third sector development-Croatia. TSI National Report No. 5, Seventh Framework Programme (grant agreement 613034), European Union. Brussels: Third Sector Impact. Retrieved from http://thirdsectorimpact.eu/documentation/tsi-national-report-no-5-identifying-externalinternal-barriers-third-sector-development-croatia/

Boje, T. P., \& Potucek, M. (Eds.). (2011). Social rights, active citizenship, and governance in the European Union. Baden-Baden: Nomos Verlag.

Brandsen, T. (2011). Social services in the Netherlands-Position and authority of non-profit sector organizations. In A. Zimmer (Ed.), Jenseits von Bier und Tulpen (pp. 75-86). Münster: Waxmann Verlag.

Brandsen, T., \& Pape, U. (2016). Barriers to third sector development in the Netherlands. TSI National Report No. 2. Retrieved from http://thirdsectorimpact.eu/documentation/tsi-national-report-no-2-barriers-to-third-sectordevelopment-in-the-netherlands/

Brudney, J. L. (2010). Volunteers. In H. Anheier, S. Toepler, \& R. A. List (Eds.), International encyclopedia of civil society (pp. 1620-1627). New York: Springer. Chabanet, D. (2016). Between traditions and changes: Institutional support to social economy in France. Arnova Conference 2016 in Washington, DC.

Chanial, P., \& Laville, J.-L. (2014). L'économie sociale et solidaire en France. In J.-L. Laville, J.-P. Magnen, G. Carvalho da Franca, \& A. Medeiros (Eds.), Action publique et économie solidaire (pp. 47-73). Paris: Erès.

Chaves, R., Alguacil-Mari, P., Fajardor-Garcia, I. G., \& Savall-Morera, T. (2016). Third sector barriers in Spain. TSI National Report No. 8. Retrieved from http://thirdsectorimpact.eu/documentation/tsi-national-report-no-8third-sector-barriers-spain/

Dedman, M. (2010). The origins and development of the European Union 1945-2008: A history of European integration. London: Routledge.

Defourny, J. (2014). From third sector to social enterprise: A European research trajectory. In J. Defourny, L. Hulgard, \& V. Pesthoff (Eds.), Social enterprises and the third sector (pp. 17-41). London and New York: Routledge.

Delors, J. (2004). The European Union and the third sector. In A. Evers \& J. L. Laville (Eds.), The third sector in Europe (pp. 206-215). Cheltenham: Edward Elgar.

Erlandsson, S., Storm, P., Strantz, A., Szebehely, M., \& Trydegård, G.-B. (2013). Marketising trends in Swedish eldercare: Competition, choice and calls for stricter regulation. In G. Meagher \& M. Szebehely (Eds.), Marketisation in Nordic eldercare: A research report on legislation, oversight, 
extent and consequences (pp. 23-84). Stockholm: Department of Social Work, Stockholm University.

European Commission. (2001). European Governance-A White Paper. $\operatorname{COM}(2001) 428$ final.

European Commission. (2014). A map of social enterprises and their eco-systems in Europe; (Country reports). European Union, 2014. Retrieved from http://ec. europa.eu/social/keyDocuments.jsp?pager.offset $=0 \& \&$ langId=en $\&$ mode $=$ ad

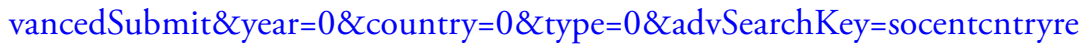
pts\&orderBy=docOrder

Freise, M., \& Zimmer, A. (2004). Der Dritte Sektor im wohlfahrtsstaatlichen Arrangement der post- sozialistischen Visegrád-Staaten. In A. Croissant, G. Erdmann, \& F. W. Rüb (Eds.), Woblfahrtsstaatliche Politik in jungen Demokratien (pp. 153-172). Wiesbaden: VS-Verlag.

Gidron, B., Kramer, R., \& Salamon, L. M. (Eds.). (1992). Government and the third sector: Emerging relationships in welfare states. San Francisco: Jossey-Bass.

Golbeck, C. (2011). Auf der Suche nach produktiven KompromissenWohlfahrtsverbände zwischen sozialem Anspruch und wirtschaftlicher Effizienz. In A. Zimmer (Ed.), Jenseits von Bier und Tulpen (pp. 87-109). Münster: Waxmann.

Havel, V., \& Keane, J. (Eds.). (1985). The power of the powerless: Citizens against the state in Central Eastern Europe. London: Taylor and Francis.

Henriksen, L. S., Smith, S. R., \& Zimmer, A. (2012). At the eve of convergence? Transformation of social service provision in Denmark, Germany, and the United States. Voluntas, 23(2), 458-501.

Hilson, M. (2010). The Nordic consumer co-operative movements. In R. Alapuro \& H. Stenius (Eds.), Nordic associations in a European perspective (pp. 215-240). Baden-Baden: Nomos.

Hoemke, P., Pahl, B., Rentzsch, C., \& Zimmer, A. (2016). External and internal barriers to third sector development in Germany. TSI National Report No. 6. Retrieved from http://thirdsectorimpact.eu/documentation/tsi-nationalreport-no-6-external-internal-barriers-third-sector-development-germany/

Huntington, S. P. (1991). The Third Wave: Democratization in the late 20th century. Oklahoma: Oklahoma University Press.

Johnston, H., \& Noakes, J. A. (2005). Frames of protest: Social movements and the framing perspective. Lanham: Rowman \& Littlefield Publishers.

Keane, J. (1998). Civil society: Old images, new visions. Stanford: Stanford University Press. 
Kendall, J., Brookes, N., \& Mohan, J. (2016a). Identifying external and internal barriers to third sector development in the UK. TSI Working Paper Series No. 1, Seventh Framework Programme (grant agreement 613034), European Union. Brussels: Third Sector Impact.

Kendall, J., Brookes, N., \& Mohan, J. (2016b). The English third sector policy in 2015: An overview of perceived barriers to realizing impact potential, Summary of research findings for Work Package 5. TSI Policy Brief No. 3. Retrieved from http://thirdsectorimpact.eu/documentation/tsi-barriersbriefing-no-1-english-third-sector-policy-in-2015/

Kendall, J., \& Knapp, M. (1996). The voluntary sector in the UK. Manchester: Manchester University Press.

Kendall, J., Will, C., \& Brandsen, T. (2009). The third sector and the Brussels dimension: Trans-EU governance work in progress. In J. Kendall (Ed.), Handbook on third sector policy in Europe. Multi-level processes and organized civil society (pp. 341-381). Cheltenham: Edward Elgar.

Leś, E., Nałęcz, S., \& Pieliński, B. (2016). Third sector barriers in Poland. TSI National Report No. 7. Retrieved from http://thirdsectorimpact.eu/documentation/tsi-national-report-no-7-third-sector-barriers-poland/

Lundström, T., \& Wijkström, F. (1997). The nonprofit sector in Sweden. Manchester: Manchester University Press.

Maier, F., Meyer, M., \& Steinbereithner, M. (2016). Nonprofit organizations becoming business-like: A systematic review. Nonprofit and Voluntary Sector Quarterly, 45(1), 64-86.

Mansfeldova, Z., Nałęcz, S., Priller, E., \& Zimmer, A. (2004). Civil society in transition: Civic engagement and nonprofit organisations in Central and Eastern Europe after 1989. In A. Zimmer \& E. Priller (Eds.), Future of civil society: Making Central European nonprofit-organizations work (pp. 99-127). Wiesbaden: VS Verlag.

Mohan, J., Kendall, J., \& Brookes, N. (2016). Third sector impact: Towards a more nuanced understanding of barriers and constraints. TSI National Report No. 1. Retrieved from http://thirdsectorimpact.eu/documentation/tsibarriers-briefing-no-2-towards-a-more-nuanced-understanding-of-barriersand-constraints/

Osborne, D., \& Gaebler, T. (1992). Reinventing government: How the entrepreneurial spirit is transforming the public sector. Reading, MA: Addison-Wesley.

Petrella, F., Richez-Battesti, N., Bruis, L., Maisonnasse, J., \& Meunier, N. (2016). Challenges for the third sector in France. TSI National Report No. 4. Retrieved from http://thirdsectorimpact.eu/documentation/tsi-narionalreport-on-challenges-for-the-third-sector-in-france/ 
Roth, R., \& Rucht, D. (Eds.). (2008). Die sozialen Bewegungen in Deutschland seit 1945: Ein Handbuch. Frankfurt: Campus-Verlag.

Rymsza, M. (2013). The two decades of social policy in Poland: From protection to activation of citizens. In A. Evers \& A.-M. Guillemard (Eds.), Social policy and citizenship: The changing landscape (pp. 305-334). Oxford: Oxford University Press.

Salamon, L. M. (1993). The marketization of welfare: Changing nonprofit and for-profit roles in the American welfare state. Social Service Review, 67(1), 16-39.

Salamon, L. M. (1994, July/August). The rise of the nonprofit sector. Foreign Affairs. Retrieved from https://www.foreignaffairs.com/articles/1994-07-01/ rise-nonprofit-sector

Salamon, L. M. (1995). Partners in public service: Government-nonprofit relations in the modern welfare state. Baltimore, MD: Johns Hopkins University Press.

Salamon, L. M., \& Anheier, H. K. (1998). Social origins of civil society: Explaining the non-profit sector cross-nationally. Voluntas, 9(3), 213-248.

Salamon, L. M., Anheier, H. K., List, R., Toepler, S., \& Sokolowski, S. W. (1999). Global civil society: Dimensions of the nonprofit sector, Volume I. Baltimore, MD: The Johns Hopkins Center for Civil Society Studies.

Salamon, L. M., Sokolowski, S. W., \& Haddock, M. A. (2017). Explaining civil society development: A social origins approach. Baltimore: Johns Hopkins University Press.

Siemieńska, R., Domaradzka, A., \& Matysiak, I. (2011). Local welfare in Poland from a historical and institutional perspective, Warsaw. WILCO Publication No. 2. Retrieved from http://www.wilcoproject.eu/national-reports-onlocal-welfare-systems-focused-on-housing-employment-and-child-care/

Siemieńska, R., Domaradzka, A., \& Matysiak, I. (2016). Warsaw: Paving new ways for participation of mothers, fathers, and children in local public and social life-The MaMa Foundation. In T. Brandsen, S. Cattacin, A. Evers, \& A. Zimmer (Eds.), Social innovations in the urban context (pp. 181-188). New York: Springer (Open Access).

Simsa, R., Herndler, M., \& Simic, Z. (2015). Third sector barriers in Austria. TSI National Report No. 3. Retrieved from http://thirdsectorimpact.eu/documentation/tsi-national-report-no-3-third-sector-barriers-in-austria/

Simsa, R., Herndler, M., \& Totter, M. (2015). Meta-analysis of SROI studiesIndicators and proxies. TSI Working Paper Series No. 6, Seventh Framework Programme (grant agreement 613034), European Union. Brussels: Third Sector Impact. 
Sivesind, K.-H. (2017). The changing roles of for-profit and nonprofit welfare provision in Norway, Sweden and Denmark. In K.-H. Sivesind \& J. Saglie (Eds.), Promoting active citizenship? Markets and choice in Scandinavian welfare. London: Palgrave Macmillan.

Staggenborg, S. (2013). Institutionalization of social movements. In D. Snow, D. della Porta, B. Klandermans, \& D. McAdam (Eds.), The Wiley-Blackwell encyclopedia of social and political movements. Oxford, UK: Wiley-Blackwell.

Steger, M. B., \& Roy, R. K. (2010). Neoliberalism: A very short introduction. Oxford: Oxford University Press.

Trætteberg, H. S., \& Sivesind, K.-H. (2015). Ideelle organisasjoners særtrekk og merverdi på helse- og omsorgsfeltet (Rapport 2015:2). Oslo: Senter for forskning på sivilsamfunn og frivillig sektor. Retrieved from http://sivilsamfunn. no/content/download/108121/1857028/file/VR_2015_2_V4_nett.pdf

Vabø, M., Christensen, K., Jacobsen, F. F., \& Trætteberg, H. D. (2013). Marketisation in Norwegian eldercare: Preconditions, trends and resistance. In G. Meagher \& M. Szebehely (Eds.), Marketisation in Nordic eldercare: A research report on legislation, oversight, extent and consequences (pp. 163-202). Stockholm: Department of Social Work, Stockholm University.

Venables, T. (2014). Panoramic view of the funding problems of the third sector and the social economy in the European Union. Revista Espanola del Tercer Sector, 27.

Wijkström, F. (2011). Charity speak and business talk: The on-going (re)hybridization of civil society. In F. Wijkström \& A. Zimmer (Eds.), Nordic civil societies at a cross-roads (pp. 27-54). Baden-Baden: Nomos.

Wijkström, F., \& Zimmer, A. (2011). Nordic civil societies at a cross-roads. Transforming the popular movement tradition. Baden-Baden: Nomos.

Zimmer, A. (Ed.). (2013). Civil societies compared: Germany and the Netherlands. Baden-Baden: Nomos.

Zimmer, A. (2014). Money makes the world go round! Ökonomisierung und die Folgen für NPOs. In A. Zimmer \& R. Simsa (Eds.), Forschung zu Zivilgesellschaft, NPOs und Engagement (pp. 163-180). Wiesbaden: Springer VS-Verlag.

Zimmer, A., Appel, A., Dittrich, C., Lange, C., Sitterman, B., Stallmann, F., et al. (2009). Germany: On the social policy centrality of the Free Welfare Associations. In J. Kendall (Ed.), Handbook on third sector policy in Europe: Multi-level processes and organized civil society (pp. 21-42). Aldershot: Edward Elgar.

Zimmer, A., \& Hoemke, P. (2016). Riders on the storm. TSOs and the European Level of Government-A contested terrain. TSI Working Paper No. 11. 
Retrieved from http://thirdsectorimpact.eu/documentation/tsi-workingpaper-no-11-riders-storm/

Zimmer, A., \& Pahl, B. (2016). Comparative report: Learning from EuropeReport on third sector enabling and disabling factors. TSI Comparative Report No.1.Retrievedfromhttp://thirdsectorimpact.eu/documentation/comparativereport-learning-europe/

Open Access This chapter is distributed under the terms of the Creative Commons Attribution 4.0 International License (http://creativecommons.org/ licenses/by/4.0/), which permits use, duplication, adaptation, distribution and reproduction in any medium or format, as long as you give appropriate credit to the original author(s) and the source, a link is provided to the Creative Commons license and any changes made are indicated.

The images or other third party material in this chapter are included in the work's Creative Commons license, unless indicated otherwise in the credit line; if such material is not included in the work's Creative Commons license and the respective action is not permitted by statutory regulation, users will need to obtain permission from the license holder to duplicate, adapt or reproduce the material. 